\title{
Ume Saami - The Forgotten Language
}

Le same d'Ume, une langue oubliée

Kuidas Ume saami keelest sai unustatud keel

\section{Florian Siegl}

\section{OpenEdition}

\section{Journals}

Édition électronique

URL : https://journals.openedition.org/efo/7106

DOI : $10.4000 /$ efo. 7106

ISSN : 2275-1947

\section{Éditeur}

INALCO

Édition imprimée

ISBN : 978-2-343-12463-6

ISSN : 0071-2051

\section{Référence électronique}

Florian Siegl, « Ume Saami - The Forgotten Language », Études finno-ougriennes [En ligne], 48 | 2017,

mis en ligne le 20 juillet 2017, consulté le 08 juillet 2021. URL : http://journals.openedition.org/efo/

7106 ; DOI : https://doi.org/10.4000/efo.7106

Ce document a été généré automatiquement le 8 juillet 2021.

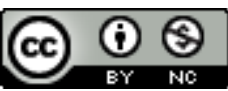

Études finno-ougriennes est mis à disposition selon les termes de la Licence Creative Commons Attribution - Pas d'Utilisation Commerciale 4.0 International. 


\title{
Ume Saami - The Forgotten Language
}

\author{
Le same d'Ume, une langue oubliée \\ Kuidas Ume saami keelest sai unustatud keel
}

Florian Siegl

\section{1. - Ume Saami - The forgotten language}

1 One of the central metaphors of Saami linguistics is the chain; the Saami languages are seen as a chain of dialects eventually turning into independent languages (e.g. Sammallahti, 1998, p.1). Whereas this metaphor is widely accepted, the English metaphor "a chain is only as strong as its weakest link" would equally fit Saami dialectology and linguistics, but to the best of my knowledge, this metaphor has not been used in print. Ume Saami is without doubts a weak link and in the following, the emergence of this situation will be reconstructed. ${ }^{1}$ What makes the Ume Saami case particularly intriguing is the fact that although Ume Saamis were seriously marginalized in the 20th century, they had played a central role in the colonizing of northern Sweden. Further, the first written Saami language of Sweden was crafted within the heart of the Ume Saami speech territory and its central features were heavily influenced by the grammar and the lexicon of Ume Saami.

\section{1. - "A chain is only as strong as its weakest link"}

2 South, Lule, North, Inari, Skolt and Kildin Saami belong to the strong links of the chain. These languages have been standardized, they have textual, grammaticographic, lexicographic and educational materials at their disposal. They are used, to varying degrees, in the media and have even attracted research beyond state borders. Even as the degree of research and documentation among the aforementioned languages differs, these languages as a whole stand in sharp contrast to Ume, Pite, Akkala and Ter Saami which are clearly the weak links in the language chain. ${ }^{2}$ Any specialist in Saami 
linguistics will probably subscribe to the claim that concerning the availability of primary materials, Ume, Akkala, and Ter Saami cannot compete with the languages I have tentatively labeled strong links. Still, although Ume, Akkala and Ter Saami are among the weakest links in the chain, it is surprisingly problematic to find a coherent pattern which would explain why these languages have attracted less research. On the other hand, there is a clear correlation between the state of documentation and the degree of endangerment: Ume, Pite, Akkala and Ter Saami are heavily if not critically endangered and except for Pite Saami, the number of specialized studies (including primary resources such as grammars, text collections, dictionaries) is low. How can this be explained? Akkala and Ter Saami have been spoken behind the Iron Curtain which prevented non-Soviet researchers from conducting primary fieldwork for most of the 20th century, but this alone does not explain why the languages have remained in the shadow of Kildin Saami. ${ }^{3}$ This argument, however, does not apply to Ume and Pite Saami which have been spoken in an area with neither restrictions on traveling nor obvious transportation obstacles. ${ }^{4}$ Furthermore, even though Ume and Pite Saami have attracted little research in the 20th century, they were actually not in an unfavorable starting position, at least symbolically. Lexically and to some degree even grammatically, Ume Saami was the cornerstone of the so called Lappish Book Language (Swedish: sydlapskt bokspråk) and was used in print; this language variety was already an object of standardization and linguistic research in the 18th century (Sköld, 1984; Wilson, 2008). Pite Saami was the native language of Israel Ruong, the first Swedish Saami with an academic degree (Ruong, 1943), the initiator of the pan-Saami Bergsland \& Ruong orthography and the first Saami professor of Sweden. However, despite this favorable starting position, neither languages could compete with South Saami and Lule Saami, their respective neighboring languages with significantly larger speech communities, both of which attracted more research.

\section{2. - When language borders, state borders and academic borders coincide}

3 Since the introduction of national borders, the Saamis have been constantly dealing with their consequences. At least until the emergence of the USSR, borders could be crossed, even though certain restrictions applied. The need for the crossing of borders is evident due to the distribution of the Saami languages across the territories of several nation-states. Families have been crossing borders and so have reindeer ever since. Nevertheless, Ume and Pite Saami occupy a different position than South, Lule and North Saami concerning borders. South Saami and Lule Saami are spoken in Sweden and Norway; North Saami is spoken in Sweden, Norway and Finland. This fact has triggered research on South, Lule and North Saami in more than just one country. In contrast, Ume Saami and Pite Saami are known only from Sweden. ${ }^{5}$ Consequently, Ume and Pite Saami fell under the responsibility of Swedish research and in this concern, Ume and Pite Saami differ sharply from South, Lule and North Saami. For Ume and Pite Saami, language borders, state borders and academic borders did indeed coincide to a very large degree. 


\section{3. - Ume Saami as a weak link}

4 Why, then, did Ume Saami become a weak link in the chain? As I will show below, a plausible explanation would run short when focusing on research history only; instead, research history and history of thought need to be approached simultaneously. In order to highlight their relation - which will occupy us more in section 5 - a short look at Israel Ruong's oeuvre is sufficient. A classic problem in Saami linguistics, then and now, is the lack of manpower. As research could not focus on all languages to the same degree, languages with larger speech communities were singled out for research, and this decision was at least partly conscious. Although Ruong's dissertation focused on his native language Pite Saami (Ruong, 1943), this was as far as I know the only linguistic study he published dedicated to his own native language. ${ }^{6}$ Other linguistic work, mainly with a dedicated educational component, concentrated on the creation of literacy and teaching materials for North Saami (e.g., Ruong, 1965, 1970).

\section{2. - From colonization to "lapp-skall-vara-lapp politics"}

5 Ume Saami used to be the dominant Saami language of the historical Åsele- and Lycksele lappmark (also known as Ume lappmark) as well as the southern parts of Pite lappmark. In comparison to other lappmark territories such as Torne- and Lule lappmark, the aforementioned territories were colonized comparatively late and contrary to general belief, not exclusively by Swedish settlers (Siegl, 2015). Whereas the first, mainly Finnish speaking colonialists arrived in the early 17th century, the main bulk of Swedish colonialists arrived almost a century later. Usually, Swedish colonialism started with the arrival of Lutheran pastors who erected churches and opened schools. Whereas the first settlers were often employees of the local church (and in Arjeplog miners), the second wave of colonialists was made up by ethnic Swedes who went inland from cities like Umeå, Skellefteå, Piteå and Luleå looking for suitable farmsteads (see Siegl, 2014, for a condensed historical overview). Simultaneously with the arrival of Swedish colonialists, speakers of Ume and especially of Pite Saami shifted from a semi-nomadic way of life to permanent settlement. This was possible because the traditional Forest Saami culture relied on small-scale reindeer herding which did not require a fully nomadic way of life. Initially, the transition did not imply drastic changes. In a later phase, economic patterns of non-Saami colonialists were copied, and Saami settlers started to herd goats, sheep and occasionally even cows. This cultural shift was followed by language shift. Already in the early 19th century, the pastor Petrus Læstadius reported that in Åsele, Frederika, Dorotea, Vilhelmina and Lycksele one could hear Saami only sporadically. In Arjeplog, Arvidsjaur, Sorsele and Stensele, Swedish started to dominate, but occasionally one could still find Saamis who hardly spoke any Swedish (Læstadius, 1928, pp. 63-65).

6 Although the on-going colonization of Ume Saami territories led to the numeric decline of Ume Saami speakers, a change in Saami politics affected the status of Ume Saamis even more profoundly. This new era in Swedish Saami politics started in the late 19th century and is known as a Lapp shall remain a Lapp (Swedish: lapp-skall-vara-lapp) politics (see Lundmark, 2002). Based on then contemporary Darwinist tendencies, the Swedish state intended to stop the increasing assimilation of Saamis by their separation 
from Swedish society and education. The continuation of a semi-nomadic life style based on reindeer husbandry was seen as the decisive means to accomplish this goal. The type of reindeer husbandry which the Swedish state had in mind was mountain reindeer husbandry (Swedish: fjällrenskötsel) which was characteristic for South Saamis and especially North Saamis who were therefore subsumed as fjällsamer 'mountain Saamis'. However, the majority of Ume, Pite, and Lule Saamis practiced a different kind of reindeer husbandry called forest reindeer husbandry (Swedish: skogsrenskötsel). ${ }^{7}$ As the lapp-skall-vara-lapp politics defined Saamis solely on economic principles, the Forest Saamis (Swedish skogssamer) 8 became an anomaly as the prototypical Saami was supposed to have a large herd of reindeer. However, many Forest Saamis had reduced reindeer herding or already given it up altogether by that time. ${ }^{9}$ From the perspective of lapp-skall-vara-lapp politics, skogssamer could neither be characterized as Saami nor Swedes and the direct outcome of this politics was the further marginalization of Forest Saamis (including Ume Saamis), who then became a minority inside a minority. This kept them from receiving subsequent attention as Saami politics focused entirely on fjällsamer and fjällrenskötsel.

\section{3. - The lappish book language and its relation to Ume Saami}

With the advent of the reformation, language issues became important because the bible was supposed to be available in the languages of subjects of the Swedish Kingdom. Whereas Swedish and Finnish bible translations were already available in the 16th century, the first known attempts for Saami in Sweden started in the early 17th century. The earliest publications of Saami language materials for church and education demonstrate that it was not understood that more than one Saami language was spoken within the borders of the Kingdom of Sweden. The first book "En lijten Sångebook, huruledes Messan skal hållas, läsas, eller siungas på Lappesko, Stält och sammansatt aff Nicolao Andreæ" (A little church manual how the service should be held, read and sung in Lappish, compiled by Nicolaus Andreæ) was published in Stockholm in 1619. The potential compiler and translator Nicolaus Andreæ (Rhen) was pastor in Piteå, but the obscure mixture of South Saami, Swedish and Finnish was apparently unsuitable for practical use. ${ }^{10}$ In 1638 , another book "Swenske och Lappeske ABC Book" (A Swedish and Saami primer) was published anonymously in Uppsala. The language of this book is considered to be Lule Saami. ${ }^{11}$ The two "Manuale Lapponicum" which were published several years later, are of further relevance. ${ }^{12}$ The first "Manuale Lapponicum" from 1648 was compiled by Johannes Tornæus who had spent several years in the Torne lappmark as a pastor. His "Manuale" contains several episodes from both the Old and the New Testament, Luther's Catechism, church ordinances, several prayers and hymns. Although the language follows the variety spoken in the Torne area, it contains some unusual elements from more southern Saami languages, and these have never been explained satisfactorily. The other "Manuale Lapponicum" by Olaus Stephani Graan from 1669 was published in a variety of Ume Saami. This "Manuale" also contained parts from different gospels, prayers, hymns and a church ordinance. In contrast to both Nicolaus Andreæ (Rhen) and Johannes Tornæus who were not native speakers of Saami, Olaus Stephani Graan was probably a native speaker of Ume Saami. 
8 From the perspective of the church, both "Manuale" were incomplete as they did not contain a complete translation of the bible. This translation task was assigned to the pastor Lars Rangius, himself a native speaker of Ume Saami, who eventually compiled a translation in the beginning of the 18th century. This translation, again into a variety of Ume Saami, was never published for unknown reasons. ${ }^{13}$ Although the translation by Rangius remained unpublished, it marked a change concerning the status of Saami. As early literacy efforts demonstrate, both South and Ume Saami started to become visible next to the Saami languages of the more northern Lule- and Torne lappmark which had been integrated into the Kingdom of Sweden much earlier. This development does not come as a surprise since the colonization of the Åsele-, Lycksele- and Pite lappmark, the area inhabited by Ume Saami speakers, had started in the meantime, which resulted in the establishment of Lycksele. For at least two centuries Lycksele, located in the heart of the Ume Saami territory, became a center of religion, jurisprudence, administration and education. As a result, it is also not surprising that the creation of the Lappish Book Language took place in Lycksele.

9 Due to the failure of the first attempts at religious literacy creation and the ongoing protestant conversion among the Saamis, research into Saami and the creation of a written language started to go hand-in-hand as non-Saami clergy needed materials for acquiring practical language skills for their work..$^{14}$ In the 1720 s, Pehr Fjellström, first a teacher and later a pastor in Lycksele, started the compilation of a dictionary and grammar and translated Svebelius' comments to Luther's Little Catechism, all of which were printed in Stockholm in $1738 .{ }^{15}$ Although the lexical base of this language was Ume Saami, its grammar was not. The fact that both umlaut and gradation were omitted have been presented as conscious choices of the author in order to make this kind of language that was easier to understand for all Saamis from South to North; furthermore, this would also have helped the Swedish speaking clergy to learn the language much more quickly. ${ }^{16}$ However, the fact that this artificial language remained incomprehensible for the Saamis themselves was not considered problematic at all.

10 Some years later, the Swedish parliament formally approached Fjellström to produce a translation of the entire New Testament. After consultations with other lappmark pastors in Arjeplog in 1743 and Umeå in 1744, Fjellström's Lappish literary language (Swedish: sydlapskt bokspråk) was approved. ${ }^{17}$ Fjellström continued to translate religious literature into this language form, and in 1755 the entire New Testament appeared in print in Stockholm..$^{18}$ Nonetheless, it still took several decades before the whole bible appeared in print in $1811 .{ }^{19}$ This form of language was used in print until the end of the 19th century before it started to fade and individual language specific orthographies for Lule and North Saami began to appear. Although the Lappish Book Language was an artificial language which was neither spoken nor acquired, and functioned in a very narrow niche dominated by religion, it was used in quite a number of printings. ${ }^{20}$ Even though the Lappish Book Language cannot be called Ume Saami in the strict sense, its Ume Saami foundation is worth mentioning at least from a cultural-historical perspective, as this Ume Saami inspired language played a decisive role in the early days of Saami literacy in Sweden. The fact that Ume Saami was spoken around the old administrative center Lycksele certainly contributed to this choice. Further, given the fact that Ume Saami was spoken in three lappmark areas, the language must have been spoken by a significant population. Otherwise one would have expected a different language to have been chosen for this purpose. Although the Lappish book language was 
indeed an artificial language, the language itself appeared to be a rather stable written language; indeed, the language originally invented by Pehr Fjellström was used for almost 160 years in print. Whereas translations were adjusted, the orthography itself remained stable. However, with the later emergence of specialized and more accurate orthographies, the Lappish Book Language died. Astonishingly, even though a sizeable body of texts exists, philological work on this language form has never caught on in Saami research.

\section{4. - Ume Saami and South Saami - Dialects of one language or two independent languages?}

11 Starting around the end of the 19th century, research on Saami languages began to focus on individual languages, dialectology, mutual relations and language history. During that period, questions concerning internal classification started to become important. ${ }^{21}$ As many languages were still only fragmentarily known, this period saw an increase in fieldwork, especially concerning languages other than North Saami.

\section{1. - Ume Saami and South Saami - A note on research history}

Early research on Ume Saami was rather international and started far away from Lapland. By chance, the Hungarian Finno-Ugrist Jozséf Budenz meet four Circus-Saamis $^{22}$ from Malå in Vienna in 1873. The materials which he was able to collect were published two years later (Budenz, 1875) and this publication contained materials on a language variety which for the first time unanimously qualifies as Ume Saami. Subsequent research, still rather international, continued in Lapland in the field and quite often among speakers of more than just one language. The first collectors of South and Ume Saami materials include the Norwegian Just Qvigstad, the Hungarian Ignácz Halász, the Finn Kaarlo A. Jaakkola and the later professor of Finno-Ugric linguistics in Uppsala, the Swede Karl Bernhard Wiklund. Whereas all four collectors gathered data on South Saami, only Halász and Wiklund collected data on both Ume and South Saami. While Wiklund focused on wordlists and some grammatical materials (which have remained almost entirely unpublished) ${ }^{23}$, Halász collected grammatical and lexical materials and a sizeable body of texts (Halász, 1885, pp. 120-126; 1887, pp. 7-168).

13 Although the initial stages of South and Ume Saami research were quite international, the situation changed after Wiklund's malevolent review of Halász's research (Wiklund 1893) which led to it being completely ignored in Scandinavia (Rydving, 2013, pp. 48-49). ${ }^{24}$ Furthermore, this review caused Ume Saami research to seemingly became a monopoly of Swedish academia. On Wiklund's initiative, his students Axel Calleberg and Nils Moosberg continued to collect data on Ume Saami up until the 1930s. ${ }^{25}$ Curiously, neither the critic Wiklund nor his students Calleberg and Moosberg published any of their Ume Saami data in support of Wiklund's criticism. While new data did not become available, the only extant sizeable data collection by Halász, despite its deficiencies, started to fall into oblivion. For the sake of completeness, the only Ume Saami materials gathered in that period which eventually were published should be mentioned. These derive from Eliel Lagercrantz's fieldwork with an Ume 
Saami from Sorsele (gathered in 1921) who had settled in Norway (published in Lagercrantz 1926a, pp. 101ff; 1939). ${ }^{26}$

Whereas the first decades of research on South and Ume Saami enjoyed a rather promising start, the situation began to change, and this resulted in additional South Saami research and a neglect of Ume Saami. Ultimately, K. B. Wiklund was responsible for this. In several writings, Wiklund predicted that the Forest Saamis would not have a future and were doomed to become extinct soon. Therefore, he claimed, the type of reindeer husbandry practiced by Forest Saamis should be given up in order to free agricultural space for Swedish farmers. Following lapp-skall-vara-lapp politics, Wiklund claimed that only those Saamis who practiced reindeer husbandry in the mountains would eventually avoid assimilation (see Karlsson, 2000: 50-51). Although Wiklund's statement was not intended to be linguistic, it affected, perhaps even unconsciously, linguistic research by causing the latter's focus to shift away from the Forest Saami languages in Sweden.

This becomes clearly visible in the work of Wiklund's successor, Björn Collinder. ${ }^{27}$ Early in his career, Collinder engaged in fieldwork and conducted research on a number of Saami languages of Sweden, among them South Saami and Ume Saami. Whereas Collinder's South Saami materials were eventually published (Collinder, 1942; 1943), Collinder's linguistic Ume Saami materials collected in Arvidsjaur in 1943 remained unpublished. ${ }^{28}$

16 This pattern continued after Collinder. Knut Bergsland and Gustav Hasselbrink, both known for their South Saami research ${ }^{29}$ and their dedication which led to the introduction of the first written standard for South Saami, also conducted research on Ume Saami. Their contribution, which was only published in the Swedish version, but not the Norwegian version of Sámien lukkeme-gärjá, included a short section on Ume Saami. This contains some grammatical notes, four texts, and a note on lexical differences (Bergsland \& Hasselbrink, 1957, pp. 65-74). This little section marks the only publication of primary Ume Saami materials in Sweden throughout the 20th century. Still, even though this section is as such rather uninformative, it is perhaps best known for a categorical statement concerning the relation of Ume Saami to South Saami. According to Bergsland and Hasselbrink, Ume Saami should be considered a variety of South Saami and not an independent language (Bergsland \& Hasselbrink, 1957, p. 65). Within Scandinavia, research on Ume Saami was continued by e.g., Tryggve Sköld, Israel Ruong, Gustav Hasselbrink and Olavi Korhonen, all of whom collected data either with pen and paper or by recording spontaneous speech. ${ }^{30}$ Unfortunately, these collections have remained on archive shelves ever since.

The only other sizeable data on Ume Saami published after Halász again derives from the work of a non-Scandinavian scholar. Wolfgang Schlachter's material from Malå, collected in the spring of 1940 in Setsele and published as Schlachter (1958) is a text collection with some rudimentary inflectional paradigms and a dictionary. The data gathered by Schlachter reflects the idiolect of Lars Sjulsson but due to the absence of other published materials except for the short section in Sámien lukkeme-gärjá (Bergsland \& Hasselbrink, 1957, pp.65-74), the idiolect of Lars Sjulsson from Malå became synonymous with Ume Saami (see e.g., Larsson, 2010, 2012).

19 This covers all primary materials for modern Ume Saami published in the 20th century and shows that despite Wiklund's critique the majority of published primary materials on Ume Saami have been compiled by non-Swedish researchers. Most certainly, Ume 
Saami does not qualify as an undocumented language as dedicated research started in the 1870s and primary materials were able to be collected until the beginning of the 21st century. What this condensed overview shows is why Ume Saami, paradoxically, is a weak link in the Saami language chain. Despite the existence of data, there is still hardly any data.

\section{2. - On idiolects, dialects, performance, competence and representativity}

20 Ideally, in order to facilitate linguistic research whose aims are to investigate the relationship between two closely related varieties such as South Saami and Ume Saami, a comprehensive corpus is required. Furthermore, such a corpus should be both balanced and representative, and include different varieties, idiolects, registers, dialects and the like. ${ }^{31}$ Concerning our current knowledge of Ume Saami, what is known about this language is diffuse and the available corpus is a collection of bits and pieces. Regarding phonetics, phonology, morphology and the lexicon, some data (archival and published) exists for Tärna, Ammarnäs, Malå and Arvidsjaur. For other areas with an earlier Ume Saami population such as Lycksele, hardly anything relevant has been collected. Concerning published textual materials, the aforementioned publications with data for Malå and Arvidsjaur can be mentioned. Regarding archival materials, the collections of Tryggve Sköld and Israel Ruong contain additional data for Malå and Arvidsjaur; for other areas, similar collections are absent and one has to hope that transliteration of spontaneous speech recordings could close some gaps, although some will remain for sure, as the number of living fluent, first-langue native speakers has practically dropped to zero. ${ }^{32}$ As a result, this means that research focusing on questions concerning the relationship between two closely related languages such as South and Ume Saami has been operating, and will be forced to continue operating with idiolectal data which is perceived to be representative for a given dialect. Larsson (2012) provides an important step, and some of the discussion below will focus on three observations whose implications are perhaps not particularly obvious at first glance.

\section{3. - Impression from the Ume Saami borders}

Given the fact that the Saami languages are seen as a chain of languages, where can one draw the border between a language and a dialect, especially when existing data is fragmentary? The following sections briefly present two instances which demonstrate problems older research had to face due to the lack of published materials but whose decisions have had some impact on research even up to today.

\subsection{1. - Ume Saami in Norway?}

A large portion of Halász's materials from the former Ume lappmark were actually collected in Hattfjelldal in Norway (Halász, 1885, pp. 7-67; 70-139; 148-168). The remaining materials derive from Sweden and are said to exemplify the variety spoken in Stensele (Halász, 1885, pp.67-70; 139-148). In a later dialectological publication, Halász (1891, pp. 227ff) classified both Hattfjelldal and Stensele as belonging to his southern Lappish speech area (Hungarian: a déli-lapp nyelvterület), together with other varieties which today would be classified as proper South Saami. In contrast, Arvidsjaur 
and Malå belong to his middle Swedish Lappish group (Hungarian: közép svéd-lapp nyelvterület) which makes up an independent sub-group of its own (Halász, 1891, pp. 210ff). ${ }^{33}$ Halász's interpretation goes against my proposition in the introduction that no Ume Saami data was ever collected among Norwegian Saamis - this seeming contradiction will be discussed below. In addition to Halász, Qvigstad also collected narratives in Hattfjelldal (in 1884 and 1887). In Qvigstad's original publication (Qvigstad, 1924), this language variety was not characterized any further beyond the general label 'Lappish from Norway'. However, in a reprint, this language variety from Hattfjelldal was considered to be an example for a very northern sub-dialect of South Saami (Qvigstad, 1996). This old unsettled problem is a perfect example for the difficulties in drawing boundaries between Ume Saami and South Saami; I avoid siding with any one interpretation for the time being as a dialectological interpretation is pending. If Hattfjelldal Saami is indeed South Saami, then Halász's contribution to Ume Saami would decrease significantly and only his materials from Stensele and Arvidsjaur would classify as Ume Saami. In this instance, the initial statement that Ume Saami was not encountered in Norway would remain correct. If Halász's assumption that Hattfjelldal Saami was Ume Saami is correct, then Qvigstad's name would end up in the list of Ume Saami documenters and Ume Saami was indeed documented in Norway. ${ }^{34}$

In order to investigate the South and Ume Saami border within a chain of dialects in which borders are by definition fuzzy, any answer requires a mix of phonological, morphological, lexical and even syntactic arguments. Larsson (2012) has rightfully emphasized this problem and has convincingly proven that there is not a single linguistic trait that would help to unequivocally identify a variety as either South or Ume Saami. Based on available evidence as contained in Qvigstad (1996), the current classification of Hattfjelldal as South Saami appears justified, although the shape of personal pronouns and the frequent use of the copula in the present tense are slightly untypical for South Saami. Nonetheless, despite the existence of published materials, the border is still unsettled as additional data on this area has never been published.

\subsection{2. - The northern border of Ume Saami}

As shown above, the southern border between South and Ume Saami, despite the existence of some linguistic data, has resisted any dialectological interpretation so far. When turning to the border between Ume Saami and Pite Sami, one finds an even more intriguing example of how a border was assumed in spite of evidence to the contrary. The map in M. Korhonen (1981) shows that the border between Ume Saami and Pite Saami was assumed to run through the town of Arvidsjaur. Given the fact that Korhonen could not have relied on any other material than the published materials mentioned in 4.1, how could he have been motivated to draw the border as he did? The only explanation is that Korhonen simply concluded that the village Arvidsjaur comprised the northernmost area because Sámien lukkeme-gärjá contained four texts purportedly from Arvidsjaur. ${ }^{35}$ However, not a single Ume Saami who contributed to Sámien lukkeme-gärjá was from Arvidsjaur at all. The three siblings Sara Maria Norsa (born Stenberg), Karin Stenberg and Nils Petter Stenberg were born in Araksuolo, almost $40 \mathrm{~km}$ northwest of Arvidsjaur at the northern end of Västre Kikkejaur. Johan Persson Ragnefjäll, the fourth consultant, was from Radnejaur, a small village $20 \mathrm{~km}$ east of Arjeplog. ${ }^{36}$ With this in mind, the northern border should run significantly farther to the north and west of the town of Arvidsjaur, as indicated by the map in 
Korhonen (1981). Whereas in the south a border has not been confirmed despite the existence of some data, in the north a border was drawn in spite of available linguistic data.

\subsection{3. - How to identify meaningful differences between South Saami and Ume Saami}

With the publication of Larsson's monograph, a profound analysis of variation within Ume Saami has become available (Larsson, 2012). Variation is often contrasted with South Saami in order to single out differences between both languages. As the monograph is based on Wiklund's, Calleberg's and Moosberg's unpublished materials, Larsson avoided the pitfalls of earlier research on Ume Saami, which assumed that Lars Sjulsson's idiolect was representative of Ume Saami. As Larsson's analysis shows, the variety of Ume Saami as spoken by Lars Sjulsson was representative for a more northern variety within Ume Saami. Varieties in the south-west around Sorsele, Ammarnäs and Tärna differed from this variety in either having no consonant gradation or only limited consonant gradation, and should be classified as the second principle dialect within Ume Saami. Larsson also provides further inner-dialectal variation in morphology and the lexicon. Although the amount of structural variation is instructive, their function had to remain unexplored due to the lack of clausal examples in the underlying data base, a topic to be discussed in more detail in section 5 below. Therefore, syntactic arguments occupy only three pages in Larsson's analysis (Larsson, 2012, p.137-140). However, if one takes syntax seriously, a number of meaningful differences between Ume Saami and South Saami become visible and I will repeat several findings of my own (Siegl 2012), to which I will add a new observation absent from both Larsson (2012) and Siegl (2012). ${ }^{37}$

\subsubsection{1. - Copula}

According to Bergsland (1994, pp.34-38; pp.46-47; pp. 50-53) South Saami allows the copula in the present tense to be dropped. If the copula is overtly expressed, a certain emphatic stress is intended. ${ }^{38}$ In contrast, in Ume Saami the copula is obligatory, as in the other Western Saami languages:

1) $\mathrm{saU}$

\begin{tabular}{|l|l|l|l|l|l|}
\hline a. & månna & leäb & \multicolumn{2}{|l|}{ Märjje } & \\
& 1SG & be.1SG & \multicolumn{2}{|l|}{ Maria. } & \\
\hline & \multicolumn{2}{|l|}{ 'I am Maria.' [Heärggie 5] } & \\
\hline \multicolumn{7}{|l}{} & \\
\hline b. & muv & bååtsuj & leä & tjappie & \\
\hline & 1SG.GEN & reindeer & be.3SG & beautiful & \\
\hline & 'My reindeer is beautiful.' [NL, IL] & \\
\hline
\end{tabular}




\begin{tabular}{|c|c|c|c|c|}
\hline c. & njibbie & leä & \multicolumn{2}{|c|}{ burtesne } \\
\hline & knife & be. $3 \mathrm{SG}$ & \multicolumn{2}{|c|}{ table.INESS } \\
\hline & \multicolumn{4}{|c|}{ 'Is the knife on the table?' [NL, IL] } \\
\hline \multirow[t]{2}{*}{ d. } & dahte & leä & bijluv & gullema \\
\hline & dem & be.3sg & car.acc & hear.ptcp.perf \\
\hline & \multicolumn{4}{|c|}{ He heard a car.' [NL, IL] } \\
\hline
\end{tabular}

\subsubsection{2. - Differential object marking} restricted to South Saami only. The following examples demonstrate its basic properties. In singular, the accusative case takes overt object marking:

29

2) saS

\begin{tabular}{|l|l|l|l|}
\hline a. & Aehtjie & ledtiem & vöötji \\
\hline & father & bird.ACC & shoot.PRT.3SG \\
\hline & 'Father shot a/the bird.' [Bergsland 1994, p. 59] \\
\hline
\end{tabular}

30 In plural, nominative encodes indefinite objects (3a) and accusative definite objects (3b):

31 3) saS

\begin{tabular}{|l|l|l|l|}
\hline a. & Laara & treavkah & dorjeme \\
\hline & Lars & ski.pl.nom & make.ptcp.perf \\
\hline & Lars has made skis.' [Bergsland 1994, p. 60 ] \\
\hline b. & Dejtie & treavkide & vööjnim \\
\hline & dem.pl.acc & ski.pl.acc & see.prt.1sg \\
\hline & \multicolumn{3}{|l}{ 'I saw those skis.' [Bergsland 1994, p. 60] } \\
\hline
\end{tabular}

32 This syntactic peculiarity is absent from Ume Saami where plural objects only appear in the accusative case:

4) $\mathrm{saU}$ 


\begin{tabular}{|c|c|c|c|c|c|c|}
\hline a. & voinad & ditte & johkide & \multicolumn{3}{|l|}{ jo } \\
\hline & see.2SG & DEM.PL.ACC & river.PL.ACC & \multicolumn{3}{|c|}{ already } \\
\hline & \multicolumn{6}{|c|}{ 'Do you see these rivers already?' [NL, IL] } \\
\hline b. & voinad & dåtne & muv & \multicolumn{2}{|c|}{ tjahppis } & buutside \\
\hline & see.2SG & $2 S G$ & 1SG.GEN & \multicolumn{2}{|c|}{ beautiful } & reindeer.PL.ACC \\
\hline & \multicolumn{6}{|c|}{ 'Do you see my beautiful reindeer?' [NL, IL] } \\
\hline \multirow[t]{2}{*}{ c } & månne & Arrviehaureje & vuolgav & \multicolumn{2}{|c|}{ biebmoide } & oasstiet \\
\hline & $1 \mathrm{SG}$ & Arvidsjaur.ILL & drive.1SG & \multicolumn{2}{|c|}{ food.PL.ACC } & buy.INF \\
\hline & \multicolumn{6}{|c|}{ 'I am driving to Arvidsjaur to buy food.' [NL, IL] } \\
\hline \multirow[t]{2}{*}{ d. } & De & nuvt & \multicolumn{2}{|l|}{ ådtjuojmen } & meärkuot & dajddie \\
\hline & part & manner & \multicolumn{2}{|l|}{ can.prt.1pl } & mark.inf & dem.pl.acc \\
\hline & miesiijde & juhk & eäh & ian & uvddale & mierkktuvvame \\
\hline & calf.pl.acc & rel.pl & neg.aux.3pl & part & before & mark.pass.ptcp.perf.cn \\
\hline & 'Sc & mark the caly & which were $\mathrm{n}$ & 1 & arlier. & Renskötsel] \\
\hline
\end{tabular}

\subsubsection{3. - Expression of possession}

34 To express possession, South Saami uses a genitive copula construction or a transitive possessive verb utnedh 'keep, have':

5) saS

\begin{tabular}{|l|l|l|l|}
\hline a. & Laaran & (lea) & bïenje \\
\hline & Lars.GEN & be.3SG & dog \\
\hline & \multicolumn{2}{|l|}{ Lars has a dog.' [Bergsland 1994, p. 53] } \\
\hline & \multicolumn{3}{|l|}{} \\
\hline b. & Stoerre & krieviem & utnin \\
\hline & large & flock.Acc & have.PRT.3PL \\
\hline
\end{tabular}


'They had a large flock.' [Bergsland 1994, p. 59] possessive-transitive verb is used: ${ }^{39}$

37

\begin{tabular}{|c|c|c|c|c|c|c|}
\hline a. & mån & adnav & \multicolumn{4}{|l|}{ adnav } \\
\hline & $1 \mathrm{SG}$ & have.1SG & \multicolumn{4}{|l|}{ car.AcC } \\
\hline & \multicolumn{6}{|c|}{ 'I have a car.' [NL, IL] } \\
\hline \multirow[t]{2}{*}{ b. } & dahte & daalhkes & itni & samma & vuossin & sisne \\
\hline & DEM & spirit & have.PRT.3SG & same & bag.GEN & in.INESS \\
\hline & \multicolumn{6}{|c|}{ 'He had the spirit in the same bag.' [1064A1] } \\
\hline
\end{tabular}

\subsubsection{4. - Predicative agreement}

Predicative adjectives do not show number agreement in South Saami:

7) $\mathrm{saS}$

\begin{tabular}{|l|l|l|}
\hline a. & Noere & dihte. \\
\hline & young & dem \\
\hline & \multicolumn{2}{|c|}{ 'He is young.' [Bergsland 1994, p. 52] } \\
\hline & \multicolumn{2}{|l|}{ noere } \\
\hline b. & Dijjieh & young \\
\hline & dem.pl & 'They are young.' [Bergsland 1994, p. 52] \\
\hline
\end{tabular}

In Ume Saami, number agreement is required (8) similar to North Saami (9) and other Saami languages:

41

8) $\mathrm{saU}$

\begin{tabular}{|l|l|l|l|l|}
\hline a. & muv & bååtsuj & leä & tjappie \\
\hline & 1SG.GEN & reindeer & be.3SG & beautiful \\
\hline
\end{tabular}




\begin{tabular}{|l|l|l|l|l|}
\hline & \multicolumn{3}{|l|}{ 'My reindeer is beautiful.' [NL] } \\
\hline & \multicolumn{3}{|l|}{} \\
\hline b. & muv & buuts & leäh & tjappie-h \\
\hline & 1 SG.GEN & reindeer.PL & be.3PL & beautiful-PL \\
\hline & \multicolumn{3}{|l}{ 'My reindeer are beautiful.' [NL] } \\
\hline
\end{tabular}

9) $\mathrm{saN}$

\begin{tabular}{|l|l|l|l|}
\hline a. & son & lea & nuorra. \\
\hline & 3SG & be.3SG & young \\
\hline & \multicolumn{2}{|l|}{ 'He is young.' } \\
\hline & \multicolumn{2}{l|}{} \\
\hline b. & sii & leat & nuora-t \\
\hline & 3PL & be.3PL & young-PL \\
\hline & 'They are young.' \\
\hline
\end{tabular}

\section{4. - The relationship between saU and saS - a final remark}

Ever since the relationship between Ume Saami and South Saami has been studied, the fact that its status is quite unclear has dominated the discussion. Although the original statement in (Bergsland \& Hasselbrink, 1957, pp. 65ff) that classified Ume Saami as dialect was based on a shallow data base, it was hardly questioned. ${ }^{40}$ Still, as Larsson has observed (2010, p. 199):

It is symptomatic that Ume Saami is treated separately in the book (Bergsland \& Hasselbrink, F.S.), in spite of the fact that the authors themselves regard Ume Saami as a dialect within South Saami.

After the publications of Larsson (2012) and Siegl (2012), it should have become obvious that there are distinctive phonological, morphological, lexical and morphosyntactic arguments for why South Saami and Ume Saami should indeed be considered two distinct languages. Despite these meaningful linguistic differences, it remains questionable whether these differences could have imposed problems in communication between South Saami and Ume Saami speakers, which due to the absence of better means would still count as a good impressionistic test concerning the dichotomy language vs. dialect. ${ }^{41}$ However, although there are meaningful differences outside traditional Saami dialectological phonology/morphology/lexicon which will be touched upon in the next section, one has to admit that in morphology both languages are indeed very close. When comparing the basic case inventory of South Saami and Ume Saami with the inventory of their closest neighbor Pite Saami, it becomes obvious 
why the traditional approach had problems in assigning Ume Saami the status of an independent language in the Saami chain of languages. ${ }^{42}$ Based on a traditional perspective, the only meaningful difference is the existence of limited consonant gradation in the majority of Ume Saami dialects. But it is unlikely that the existence of gradation saU maannaa <NOM.SG> 'child' maanaah <NOM.PL> 'children' versus saS maana $<$ NOM.SG> vs. maanah <NOM.PL> would have made communication problematic.

Table 1 - Case suffix inventory for saS, saU and saP.

\begin{tabular}{|c|c|c|c|c|c|c|c|c|}
\hline \multicolumn{3}{|c|}{ saS (Bergsland 1994) } & \multicolumn{3}{|c|}{ saU (Korhonen \& Barruk, n.d.) } & \multicolumn{3}{|c|}{ saP (Lehtiranta 1992) } \\
\hline & SG & PL & & SG & PL & & SG & PL \\
\hline NOM & & $-h$ & NOM & & $-h$ & NOM & & \\
\hline GEN & $-n$ & $-j,-i$ & GEN & $-n$ & $-i j$ & GEN & - & $(-j)$ \\
\hline ACC & $-m$ & -ide/-idie & ACC & $-v /-b$ & -ijde & ACC & $-v$ & $-j t$ \\
\hline ILL & $-(a) n,-s e /-a s s e$ & -ide, idie & ILL & $-j e$ & -ijde & ILL & $-j$ & $-t a$ \\
\hline INESS & -sne/-isnie & -ine/-inie & INESS & -sne & -ijsne & INESS & $-n$ & $-n$ \\
\hline ELAT & -ste/-istie & -jste/-ijstie & ELAT & -ste & -ijste & ELAT & $-s t$ & $-s t$ \\
\hline com & -ine/-inie & $-j,-i+g u(e) j m i e$ & сом & $-n e$ & -jguime & com & $-j n(a)$ & $-j$ \\
\hline ESS & -ine/inie & & ESS & ESS & & ESS & $-n$ & \\
\hline
\end{tabular}

\section{5. - Why do we know so little about Ume Saami?}

As mentioned in the introduction, an account focusing entirely on research history is not sufficient to explain why Ume Saami has become a weak link in the chain of Saami languages. Neither geographical nor historical reasons seem to have hindered research on Ume Saami. However, when one takes the history of thought into consideration, further distinctive arguments become available and as a matter of fact, several have already been introduced in disguise in the previous section and will be re-approached below. As structural properties have turned out not to be decisive, a closer look at the concept of language prevailing at the height of early investigations is instructive and offers further hints.

\section{1. - Earlier concepts of language}

A general problem in earlier Saami research was the rather weak differentiation between language and dialect and quite often, both labels were seemingly used interchangeably. For reasons of simplicity, some examples from the writings of K. B. Wiklund are sufficient to demonstrate this point. Wiklund's first major publication, his dissertation, was based on his fieldwork and focused on "Lule Lappish 
dialects" (Wiklund, 1891). Three years later, Wiklund published a short Lappische Chrestomathia in Helsinki which predominantly covered North Saami (Wiklund, 1894). Several years later, Wiklund published his famous textbook Lärobok $i$ lapska språket (Textbook for the Lappish language) and although Lule Saami is the dominating language of this book, it contains further examples of written North Saami and some pages in the already obsolete Lappish Book Language (Wiklund, 1901/1915). In roughly 25 years, the same author referred to Lule Saami as a Lappish dialect, a Lappish language or simply as Lappish. This terminological inconsistency 'language' vs. 'dialect', which was by no means restricted to Wiklund, makes it hard if not impossible to clarify the status of neighboring Saami languages and its conceptualization in his and other research. ${ }^{43}$

Apart from the seemingly free variation between 'language' and 'dialect' at that time, there is at least one other problem connected to the concept 'language'. For Wiklund and his contemporaries, the decisive theoretical framework was historical-comparative (see Hovdhaugen et al., 2000, pp.370-386; especially p.385). Language had to be investigated from a dialectological/historical perspective and this perspective singled out phonetics, inflectional and derivational morphology and the lexicon as the central tasks of investigation. Consequently, the resulting picture of language was structural and by definition incomplete. The collection of clausal examples and texts was not prioritized in those days, unless materials had a clear educational purpose. Following these preliminaries, Wiklund, Calleberg and Moosberg collected paradigms and words among Ume Saamis, but hardly any clausal examples and apparently no texts. Surprisingly, a dedicated follower of the historical-comparative tradition such as Björn Collinder did indeed collect textual material, at least for South Saami, but even then, texts have played a minor role in his work. ${ }^{44} \mathrm{~A}$ certain change in perspective can be identified in later work. Bergsland and Hasselbrink as well as Wolfgang Schlachter focused on the collection of narratives; the same is true for Tryggve Sköld, whose sizeable collection contains a wealth of narratives.

Finally, given that two varieties such as South Saami and Ume Saami appear structurally close, earlier research would have been required to assemble sufficient material on all levels of grammar for comparative work in order to approve or disprove proximity. As we know today, this has not happened. Whereas prior Saami research assumed that Ume Saami was simply a variety of South Saami with limited consonant gradation and some additional differences in the lexicon, this perspective could only be uphold by relying on a structural-historical concept of language focusing only on phonetics/phonology, morphology and the lexicon. As the syntacto-centric perspective in section 4 has shown, there are indeed morphosyntactic differences between South Saami and Ume Saami, but this perspective was excluded by the dominant view of language during the first half of the 20th century, and to some degree even later.

\section{2. - Collecting materials for the sake of collecting?}

49 Despite the lack of published materials, Ume Saami is certainly not unknown and sizeable written collections exist at the Institute for Language and Folklore in Uppsala. However, the size of this collection only becomes understandable when one has a chance to browse through archive shelves and the database of digitized sound recordings. After two intensive weeks in those archives searching and inventorying 
Ume Saami materials, I have come to the conclusion that in earlier days, data collection must have been understood as a goal of its own that did not necessarily presuppose later publication. Whereas several manuscripts of Calleberg were re-written for potential publication, the vast amount of written data gathered by e.g., Valter Jansson, Björn Collinder, Israel Ruong or Tryggve Sköld were deposited unaltered and apparently were never intended to be published. As Saami studies continues to suffer from a constant lack of manpower, just the amount of written data accumulated on Ume Saami alone would require the life-times of several researchers just to turn primary materials into a publishable format. Unfortunately, it remains unclear how this is to be achieved in an academic world without permanent positions and with an increasing focus on short-term projects which by definition stand in opposition to the creation of primary materials.

\section{6. - Conclusions}

The task of this article was to reconstruct the major steps due to which Ume Saami has ended up as a weak link in the chain of Saami languages. By approaching this question from the perspective of research history and history of thought, it could be shown that this development was triggered by the prevailing intellectual situation in Saami linguistics in the early 20th century. Consequently, Ume Saami was doomed to become a victim of traditional historical-comparative Lappology. As the phonetics/ morphology/lexicon approach produced few significant or meaningful differences in the initial comparison between Ume and South Saami, there was apparently little motivation for more detailed investigation. Furthermore, due to the lack of a published body of Ume Saami material, this could not even be attempted. ${ }^{45}$ As a result, the proposition that Ume Saami should be considered a dialect of South Saami was able to be upheld for a long period.

51 As I have shown, this development is surprising for a number of reasons. First, Ume Saami has been spoken in an area which was relatively easy to access. Second, many Ume Saamis appeared in the publications of the ethnologist Ernst Manker and could have easily been consulted. ${ }^{46}$ Third, the endangered status of both Forest Saami culture and Forest Saami languages was recognized; this even resulted in initial documentation attempts by Wiklund and later documentation by his students Calleberg and Moosberg, and yet did not result in any publications. Fourth, Ume Saami was hardly unknown thanks to its role in early Swedish Saami literacy ventures as well as to initial Hungarian research. Despite Wiklund's malevolent review of Halász's research and the idea that the Saami languages of Sweden should be investigated predominantly by Swedish linguists, Swedish linguistic research has produced little relevant primary material on the Saami languages of Sweden ${ }^{47}$ Although the archives in Uppsala hold a myriad of materials, for as long as they remain unpublished, their neglect will certainly continue. Ironically, a significant amount of primary data has been compiled by non-Swedish researchers on Ume and Pite Saami, e.g. Eliel Lagercrantz (1926b, 1957, 1963), Wolfgang Schlachter (1958), Juhani Lehtiranta (1992), Joshua Wilbur $(2014,2016)$ and in my current project. In theory, Ume Saami is hardly undocumented as any visit to Uppsala quickly demonstrates. In practice however, the language has remained underdocumented as archival data has not been investigated until recently (Larson, $2010,2012,2014)$. Concerning the current language, the only published study remains 
(Siegl, 2012) which is based on material collected during two visits to Arvidsjaur in 2011. As the situation concerning access to native speakers and rememberers has deteriorated significantly, it appears that new data cannot be collected anymore. Ultimately, this means that any Ume Saami research is now entirely dependent on archival materials.

\section{Gloses}

\begin{tabular}{|l|l|l|}
\hline e.g., & 1SG & VERBAL SUFFIX \\
\hline e.g., & 1SG & NOMINATIVE PRONOUN (here first person singular) \\
\hline e.g., & 1SG.GEN & PRONOUN GENITIVE CASE (here first person singular) \\
\hline ACC & ACCUSATIVE CASE \\
\hline CN & CONEGATIVE \\
\hline DEM & DEMONSTRATIVE \\
\hline ILL & ILLATIVE CASE \\
\hline INESS & INESSIVE CASE \\
\hline INF & INFINITIVE \\
\hline NEG.AUX & NEGATIVE AUXILIARY \\
\hline NOM & NOMINATIVE CASE \\
\hline PART & PARTICLE \\
\hline PASS & PASSIVE \\
\hline PL & PLURAL \\
\hline PRT & PRETE.PERF & PERFECT PARTICIPLE \\
\hline
\end{tabular}




\section{BIBLIOGRAPHIE}

ANDERSSON Ando, 1993, Maam dah soptsestamme, Jokkmokk: Sámi girjjit.

BAGLO Cathrine, 2012, "På ville veger? Levende utstillinger av samer i Europa og Amerika", Nordisk museologi, pp. 107-116.

BERGSLAND Knut, 1943, "Røros-samiske tekster", Nordnorske samlinger, 2, Etnografisk museums ved Universitet i Oslo, pp. 163-333.

BERGSLAND Knut, 1946, Røros-lappisk Grammatik, Instituttet for sammenlignende kulturforskning, Serie B, Skrifter 43, Oslo.

BERGSLAND Knut, 1994, Sydsamisk grammati, 2, Utgave, Karasjok: Davvi Girji.

BERGSLAND Knut \& HASSELBRINK Gustav, 1957, Sámien lukkeme-gärjá. Sydlapisk läsebok med grammatik och ordlista (svensk upplaga), Oslo.

BERGSLAND Knut \& MAGGA MATTSON Lajla, 1993, Åarjelsaemien-daaroen baakoegæerja, Oslo: Iđun.

BUDENZ József, 1875, "Svéd-lapp nyelvmutatványok", Nyelvtudományi Közlemények, 12, pp. 161-220.

COLLINDER Björn, 1942, Lappische Sprachproben aus Härjedalen, Uppsala: Almqvist \& Wiksell.

COLLINDER Björn, 1943, Lappisches Wörterverzeichnis aus Härjedalen, UUÅ 1, Uppsala.

FJELLSTRÖM Phebe, 1985, Samernas samhälle i tradition och nutid, Stockholm: Norstedt \& Söners Förlag.

FORSGREN Tuuli, 1988, Samisk kyrko- och undervisningslitteratur i Sverige 1619-1850, Umeå: Scriptum. HALÁSZ Ignácz, 1885, Svéd-lapp nyelv I. Lule-és Pite-lappmarki nyelvmutatványok és szótár, Ugor Füzetek 7 II, Budapest.

HALÁSz Ignácz, 1887, Ume- és tornio-lappmarki nyelvmutatványok (Svéd-lapp nyelv III), Budapest.

HALÁSz Ignácz, 1891, "A svédországi lapp nyelvjárások", Nyelvtudományi Közlemények, 22, pp. 161-259.

HASSELBRINK Gustav, 1944, Vilhelminalapskans ljudlära: med särskild hänsyn till första stavelsens vokaler, Uppsala: Almqvist \& Wiksell.

HASSELBRINK Gustav, 1958, "Lapska psalmböcker i Sverige”, Forum Theologicum X, pp. 19-51.

HASSELBRINK Gustav, 1965, “Alternative Analyses of the Phonemic System in Central South-Lappish", Indiana University publications, Uralic and Altaic Series, 49, Bloomington: Indiana University.

HASSELBRINK Gustav, 1981-1985, Südlappisches Wörterbuch = Oårj'elsaamien baaguog'ärjaa, Skrifter utgivna genom Dialekt- och folkminnesarkivet i Uppsala Ser. C, Lapskt språk och lapsk kultur 4, Uppsala: Lundequistska bokhandeln.

HEDLUND Cecilia, 2012, “Some Remarks on the Verb lea- 'be' in old Härjedalen Sámi”, in WINKLER Eberhard et al., Lapponicae investigationes et uralicae - Festschrift zum 65. Geburtstag von Lars-Gunnar Larsson, Veröffentlichungen der Societas Uralo-Altaica 82, Wiesbaden: Harrasowitz, pp. 47-59. 
HOVDHAUGEN Even, KARLSSON Fred, HENRIKSEN Carol \& SIGURD Bengt, 2000, The History of Linguistics in the Nordic Countries, Helsinki: Societas Scientiarium Fennica.

JOHANSSON Levi, 1967, Bebyggelse och folkliv i det gamla Frostviken, 2, Upplaga, Fallköping.

KARLSSON Christer, 2000, "Vetenskap som politik - K. B. Wiklund, staten och samerna under 1900-talets första hälft", Kulturens frontlinjer - skrifter från forskningsprogrammat Kulturgräns Norr, 25, Umeå Universitet.

KORHONEN Mikko, 1981, Johdatus lapin kielen historian, Suomalaisen kirjalisuuden seuran toimituksia 370, Helsinki: SKS.

KORHONEN Olavi \& BARRUK Henrik, 2010, Kurs i umesamiska (2010-02-07).

LAGERCRANTZ Eliel, 1923, Sprachlehre des Südlappischen nach der Mundart von Wefsen, Kristiania Etnografiske Museum, 1, Kristiania.

LAGERCRANTZ Eliel, 1926a, Wörterbuch des Südlappischen nach der Mundart von Wefsen, Instituttet for sammenlignende kulturforskning, Serie B, Oslo: Aschehoug.

LAGERCRANTZ Eliel, 1926b, Sprachlehre des Westlappischen nach der Mundart von Arjeplog, MSFOu LV, Helsinki: Suomalais-Ugrilainen Seura.

LAGERCRANTZ Eliel, 1939, Lappische Wortschatz, Lexica Societatis Fenno-Ugricae VI, Helsinki: Suomalais-Ugrilainen Seura.

LAGERCRANTZ Eliel, 1957, Lappische Volksdichtung 1, West- und südlappische Texte, MSFOu 112, Helsinki: Suomalais-Ugrilainen Seura.

LAGERCRANTZ Eliel, 1963, Lappische Volksdichtung 6 - Texte aus den See-, Nord-, West-, und südlappischen Dialekten, MSFOu 126, Helsinki: Suomalais-Ugrilainen Seura.

LARSSON Lars-Gunnar, 1997, "Prästen och ordet, Ur den samiska lexikorafins historia", LexicoNordica, 4, pp. 101-117.

LARSSON Lars-Gunnar, 2010a, “Ume Saami Language Variation, I”, in Csúcs Sándor et al. (eds.), Congressus XI Internationalis Fenno-Ugristarum, Piliscsaba 9-14.VIII.2010, Pars I: Orationes plenariae, Piliscsaba, pp. 193-224.

LARSSON Lars-Gunnar, 2012, „Grenzen und Gruppierungen im Umesaamischen“, Veröffentlichungen der Societas Uralo-Altaica, 83, Wiesbaden: Harrasowitz.

LARSSON Lars-Gunnar, 2014, "Epenthetic Vowels in Ume Saami Gradation”, in NoBUfUMI Inaba et al. (eds.), Juuret marin murteissa, latvus yltää Uraliin. Juhlakirja Sirkka Saarisen 60-vuotispäiväksi 21.12.2014, MSFOu 270, Helsinki: Suomalais-Ugrilainen Seura, pp. 163-174.

LEHTIRANTA Juhani, 1992, Arjeploginsaamen äänne- ja taivutusopin pääpiirteet, MSFOu 212, Helsinki: Suomalais-Ugrilainen Seura.

LUNDMARK Lennart, 2002, "'Lappen är ombytlig, ostadig och obekväm', Svenska Statens samepolotik i rasismens tidevarv", Umeå, in FJELLSTRÖM Phebe, 1985, Samernas samhälle i tradition och nutid, Stockholm.

LÆSTADIUS Petrus, 1928, Journal, Första åren av hans tjänstegöring såsom missionär i lappmarken, Stockholm: Nordstedt \& Söners förlag.

MANKER Ernst, 1968, Skogslapparna i Sverige, Acta Lapponica XVIII, Stockholm.

NORDIN Åsa, 2002, "Relationer i ett samiskt samhälle", En studie i skötesrensystemet $i$ Gällivare socken under första hälften av 1900-talet, Sámi dutkan, 2, Umeå universitet. 
QVIGSTAD Just \& WIKLUND Karl Bernhard, 1899, Bibliographie der lappischen Literatur, MSFOu 13, Helsinki: Suomalais-Ugrilainen Seura.

QVIGSTAD Just, 1926, „Lappische Erzählungen aus Hattfjelldalen”, Kristiania Etnografiske Museum Skrifter Bind I Hefte, 4, pp. 253-315.

QVIGSTAD Just, 1996, Aarporten jih Åarjel-smaaregen soptsesh, Kautokeino: Samisk utdanningsråd. RUONG Israel, 1943, Lappische Verbalableitung dargestellt auf Grundlage des Pitelappischen, Uppsala. RUONG Israel, 1965, Niilas ja su sii'da, Uppsala: Almqvist \& Wiksell.

RUONG Israel, 1970, Min sámigiella, Lärobok i samiska, Uppsala: Utbildningsförlaget.

SAMMALlaHTI Pekka, 1998, The Saami Languages - an introduction, Karasjok: Davvi Girji.

SCHLACHTER Wolfgang, 1958, Wörterbuch des Waldlappendialektes von Malå und Texte zur Ethnographie, Lexica Societatis Fenno-Ugricae XIV, Helsinki: Suomalais-Ugrilainen Seura.

SCHLACHTER Wolfgang, 1991, "Stufenwechselstörungen im Malålappischen - Aufbau oder Abbau eines Systemes?", Veröffentlichungen der Societas Uralo-Altaica, 33, Wiesbaden: Harrasowitz.

SIEGL Florian, 2012, "Strövtåg i umesamiskan", in WINKLER Eberhard et al. (eds.), Lapponicae investigationes et uralicae, Festschrift zum 65. Geburtstag von Lars-Gunnar Larsson, Veröffentlichungen der Societas Uralo-Altaica, 82, Wiesbaden: Harrasowitz, pp. 203-217.

SIEGL Florian, 2014, „Grundzüge der Kolonisation im südlichsten Verbreitungsgebiet der Saamen des schwedischen Königreichs nach 1650", Historisches Jahrbuch im Namen der Görres-Gesellschaft, pp. 134, 251-279.

SIEGL Florian, 2015, „Die Waldsaamen Schwedens im vermeintlich leeren Raum“, in AscHE Mathias \& NigGEMANN Ulrich (Hg), Der Topos des leeren Raums als narratives Konstrukt, Historische Mitteilungen im Auftrage der Ranke-Gesellschaft, Beihefte 92, pp. 137-152.

SIEGL Florian, under review,"Tryggve Sköld och umesamiskan - impressioner från en oavslutad språkdokumentation".

SIEGL Florian \& RIESSLER Michael, 2015, “Uneven Steps to Literacy: The History of the Dolgan, Forest Enets and Kola Sámi Literary Languages”, in MARTEN Heiko, SAARIKIVI Janne, RIESSLER Michael \& TOIVANEN Reetta (eds.), Cultural and Linguistic Minorities in the Russian Federation and the European Union: Comparative Studies on Equality and Diversity, Multilingual Education, 13, Heidelberg/New York: Springer, pp. 189-230.

SVONNI Mikael, 2006, "Umesamiskan - det gåtfulla språket", in AMFT Andrea \& SVoNNI Mikael (eds.), Sápmi Y1K - Livet $i$ samernas bosättningsområde för ett tusen år sedan, Sámi dutkan, 3, Umeå, pp. 151-170.

SKöLD Trygvve, 1984, "Pehr Fjellström och det svensksamiska skrifspråket", Saga och Sed, pp. 15-26.

WIKLUND Karl Bernhard, 1891, Laut- und Formenlehre der Lule-lappischen Dialekte, Göteborgs kongliga Vetenskaps och Vitterhets Samhälles Handlingar, Ny tidsföljd 25, Göteborg.

WIKLUND Karl Bernhard, 1893, „Die südlappischen forschungen des Herrn Dr. Ignacz Halász“, JSFOu 11,2, pp. 1-27.

WIKLUND Karl Bernhard, 1894, Kleine lappische Chrestomathie mit Glossar, Hilfsmittel für das Studium der finnisch-ugrischen Sprachen I, Helsinki: Suomalais-Ugrilainen Seura. 
WIKLUND Karl Bernhard, 1913, „Stufenwechselstudien”, Le Monde Oriental, 7, pp. 197-239.

WIKLUND Karl Bernhard, 1915, Lärobok i lapska språket, Andra, reviderade upplagan, Uppsala.

WILBUR Joshua, 2015, “A grammar of Pite Saami”, Studies in Diversity Linguistics, 5, Berlin: Language Science Press.

WILBUR Joshua, 2016, „Pitesamisk ordbok samt stavningsregler”, Samica, 2, Universität Freiburg. WILSON Karin, 2008, „Markusevangeliet i Lars Rangius samiska översättning från 1713”, Acta

Academiae Regiae Gustavi Adophi CI, Uppsala.

\section{NOTES}

1. Background information on the language, the sociolinguistic status-quo and research history have been discussed elsewhere (Siegl, 2012, under review; Larsson, 2012).

2. After the publication of Wilbur $(2014,2016)$, Pite Sami is now the strongest link in this group.

3. Of course, from the perspective of Soviet planning policies, the fact that Kildin Saami, as the largest Saami language of the area, became instrumentalized for standardization and resulting pedagogical activities is understandable (see Siegl \& Rießler, 2015). Nevertheless, this is only a partial explanation.

4. The inlandsbana railway connected these areas from the late 1920 s.

5. Ume and Pite Saami were apparently once spoken in the Nordland county in Norway and these areas appear on the standard dialectological Saami maps (Korhonen, 1981; Sammallahti, 1998). However, when inspecting existing language materials, one has to conclude that this assumption is indeed programmatic, but not verified. The only materials gathered in Norway derive from Eliel Lagercrantz's fieldwork who gathered Pite and Ume Saami materials in Nordland county in 1921. However, Lagercrantz mentioned several times that all his consultants were originally from Sweden and tended to reside in Norway temporarily. Given that Lagercrantz spent two months in the area but worked exclusively with Pite and Ume Saamis from Sweden and did not mention any Norwegian Saamis speaking these languages, one wonders whether there still were any speakers left even in 1921. This interpretation would find further support by an observation by Wilbur who writes: "Ethnic Pite Saami individuals from Norway have indicated to me that the last Pite Saami speakers on the Norwegian side died several generations ago" (2014, p. 4).

6. Ruong collected materials on several Saami languages. However, the vast majority were never published and perhaps, were never intended for publication.

7. Speakers of Ume Saami in Tärna and Ammarnäs practiced fjällrenskötsel, but the majority of Ume Saami speakers resided in areas where only skogrenskötsel was possible (Fjellström, 1985, p. 149ff).

8. Ume Saamis (excluding those from Tärna and Ammarnäs), Pite and Lule Saamis and the assimilated Saami minority in the former Kemi lappmark have been subsumed under this label.

9. Manker (1968) mentioned that reindeer of Forest Saamis who had chosen to settle permanently were often integrated into herds of relatives. A similar system was known among South Saami and Lule Saami (Johansson, 1967; Nordin, 2002).

10. See the comments by Hasselbrink (1958, p. 25) and Sköld (1984, p. 15).

11. Sköld (1984, p. 16).

12. See Hasselbrink (1958, pp. 25-27); Sköld (1984, p. 16); Forsgren (1988, pp. 13ff).

13. See Wilson (2008, pp. 11-13).

14. See Forsgren (1988, pp. 33ff). Whether the existence of more than one Saami language within the Kingdom of Sweden was understood at that point also remains doubtful. 
15. Whether Fjellström was a native speaker of Ume Saami, remains unclear.

16. See Sköld (1984, p. 19).

17. The main work was done by Fjellström, though apparently he was assisted by other lappmark pastors (Forsgren 1988, pp. 37-38). The fact that the northernmost Saamis of the Kingdom of Sweden would not understand this language was apparently understood, but did not result in any obvious adaptations (Forsgren 1988, pp. 40-41).

18. Hasselbrink (1958, pp. 28-30); Forsgren (1988, p. 41ff).

19. Fjellström taught Saami to Swedish pastors in Lycksele and most of these pastors assisted him later in translation tasks. Eric Lindahl and Johan Öhrling who published the monumental dictionary Lexicon lapponicum (1780) were among Fjellström's pupils. For further background information see Hasselbrink (1958, pp. 20-30, 34) and Larsson (1997, p. 107).

20. A comprehensive bibliography of translated literature can be found in Qvigstad \& Wiklund (1899), Hasselbrink (1958) and Forsgren (1988).

21. A recent useful overview is Rydving (2013).

22. For more on Circus-Saamis, see Baglo (2012).

23. Wiklund's only publication with some Ume Saami language data is Wiklund (1914).

24. It appears that Wolfgang Schlachter (1991) was the only researcher who took Halász's research into consideration at all.

25. See the detailed discussion of their materials in Larsson (2012).

26. Otherwise, Lagercrantz is better known as a researcher of South Saami (e.g., Lagercrantz, 1923, 1926a, 1957, 1963). The fact that, in addition to his own South Saami materials, Lagercrantz also published the materials collected by K.A. Jaakkola, which are among the oldest South Saami materials available, is often overlooked.

27. Another reason why prior Forest Saami research was neglected was the problematic relationship between Collinder and Wiklund. Legend has it that Wiklund did not want to see Collinder appointed his successor and their relation was characterized as cordial disliking. It appears that Collinder initialized a neglect of Wiklund's and his students' prior Ume Saami research. Whereas Wiklund's review of Halaśz research led to the marginalization of early Hungarian research, Collinder's neglect of Wiklund's, Calleberg's and Moosberg's work resulted in a different neglect of a massive body of archival materials.

28. Collinder's Ume Saami research, its meager results and its implication for Tryggve Sköld's later research on Ume Saami is discussed in Siegl (under review).

29. Bergsland (1943, 1946, 1994); Bergsland \& Hasselbrink (1957); Bergsland \& Magga Mattson (1993); Hasselbrink (1944, 1965, 1981-1985).

30. This list is by no means final and is continued in Siegl (under review).

31. Schlachter (1991, pp. 111ff) has discussed this topic in great detail and the interested reader should consult this passage. Similar thoughts can be found in Larsson (2012, pp. 47-52).

32. See Siegl (under review) for more on the current sociolinguistic situation.

33. In contemporary Saami dialectology, Stensele, Malå, and Arvidsjaur would all be considered Ume Saami.

34. This unsettled matter as such is not unproblematic as this would affect the status of Hattfjelldal, which currently is considered a core South Saami language area in Norway.

35. A trip to Uppsala and any familiarity with Calleberg's materials would have shown that Calleberg collected Ume Saami data around Moskosel, $40 \mathrm{~km}$ north of Arvidsjaur.

36. These four individuals, their families and the history of their kin were mentioned numerous times in Ernst Manker's publications (e.g., Manker, 1968) where such data could have been retrieved easily.

37. Additional work with Ume Saami legacy data has shown that all previous propositions are essentially still correct. All examples are taken directly from Siegl (2012). 
38. In principle, this should better be understood as a trend since the copula is realized quite often in Qvigstad's Hattfjelldal texts (gathered in the 1880s) and Andersson (gathered 1942, published 1992). Hedlund (2012) offers a detailed analysis of this based on Collinder's collected materials from Härjedalen (collected 1941, published 1942, 1943).

39. This is shared with Pite Saami (see Siegl, 2012; Wilbur, 2014, p. 237).

40. Notable exceptions are Sammallahti (1998, pp. 22-24) and Svonni (2005).

41. Presumably, lexical differences should have had more negative effects, but this assumption can no longer be tested.

42. Rydving's statement that he "...regards the Ume Saami language area as a transition area" is representative (Rydving, 2013, pp. 62-65, especially p. 63).

43. Even the title of Korhonen's textbook is a belated representative of this terminological ambiguity (Korhonen, 1981).

44. Collinder can at least be credited for having made the first gramophone recordings of Ume Saami narratives in Arvidsjaur in 1943, although these remain unpublished (see Siegl under review).

45. Larsson (2012) has certainly closed an important gap by analyzing archival materials and discussing them in print. However, no primary materials beyond the examples he discusses are included in his monograph.

46. In Siegl (2012) I have tried to show that Schlachter chose Lars Sjulsson due to his role as a major consultant for Ernst Manker. Tryggve Sköld also relied on the contacts of prior investigators.

47. The monumental dictionaries by Hasselbrink (1981-1985) and Grundström (1946-1945) are not counter arguments; both compilers were pastors and acquired the languages of the communities they served to benifit their practical, everyday work. While Hasselbrink did earn a degree in linguistics (Hasselbrink, 1944), he used to published in other fields. Grundström also published extensively, but usually from a folkloristic perspective and, as far as I know, never on linguistics. As a matter of fact, even Calleberg was a pastor in Sorsele, which explains how he was able to amass sizeable data for several Ume Saami varieties.

\section{RÉSUMÉS}

Avec le same de Pite, d'Akkala et de Ter, le same d'Ume fait partie des langues sames faiblement étudiées. Cela tient manifestement au fait que l'étude des langues sames s'est concentrée sur les langues les plus parlées, laissant dans l'ombre les autres. En même temps, il faut reconnaître que cette évolution ne manque pas d'étonner, car le same d'Ume présentait quelques avantages qui auraient pu lui garantir une place parmi les langues bien étudiées sur le long terme. En effet, il était parlé au cœur de la Laponie historique, autour de Lycksele, centre ecclésiastique et culturel : c'est ainsi qu'il a joué un rôle important dans l'histoire du développement de la langue littéraire dite "same » de Suède. Sans doute cependant c'est sa similitude structurelle avec le same du Sud qui lui a été fatale. Comme la samologie historico-comparative des débuts n'était pas en mesure de tirer au clair les différences entre les deux langues, le same d'Ume a été longtemps classifié comme un dialecte du same du Sud. C'est ainsi que la recherche s'est de plus en plus concentrée sur le same du Sud, ce qui a conduit au fait que le same d'Ume a été presque entièrement ignoré. Certes, cette langue a été largement collectée, notamment au début du 
$\mathrm{xx}^{\mathrm{e}}$ siècle, mais nos connaissances sur cette langue restent aujourd'hui élémentaires et lacunaires, car les matériaux existants n'ont jamais été publiés. Cet article reconstruit aussi bien, du point de vue de l'histoire des idées que de l'historiographie, la manière dont le same d'Ume est devenu une langue oubliée : il ne faut pas négliger le rôle de relations personnelles compliquées (Wiklund avec Halász et Collinder avec Wiklund) ainsi que les théories linguistiques de l'époque.

Ume saami keel kuulub koos Pite, Akkala ja turjasaami keeltega nende saami keelte hulka, mis on siiamaani puudulikult uuritud. Nende puuduliku kirjelduse tingib ilmselt tõsiasi, et saami keelte uurimine keskendus suurematele saami keeltele ja jättis väiksemad unarusse. Samas Ume saami keele vaatevinklist tuleb tunnistada, et selline areng toimus mõnevõrra üllatuslikult, sest Ume saami keelel oli tegelikult mitmeid eeldusi, mis oleks võinud tagada selle pikaajalise uurimise. Ume saami keelt räägiti keset ajaloolist Lapimaad, selle koolitus- ja kirikukeskuse Lycksele ümbruses ja seetõttu oli tal ka tähtis roll esimese nn rootsilapi raamatukeele arenguloos. Ilmselt aga sai Ume saami keelele saatuslikuks selle strukturaalne sarnasus lõunasaami keelega. Kuna varajane ajaloolis-võrdlev lapoloogia ei suutnud olemasolevaid erinevusi nende kahe keele vahel välja selgitada, klassifitseeriti Ume saami keelt pikalt lõunasaami murdena. Niisiis keskendus uurimine üha rohkem lõunasaami keelele, mis viis selleni, et Ume saami keelt ignoreeriti peaaegu täielikult. Ume saami keelt on küll kogutud palju, eriti just 20. sajandi alguses, kuid praegused teadmised selle keele kohta on jätkuvalt algelised ja lünklikud, sest olemasolevat materjali pole kunagi avaldatud. Käesolevas artiklis rekonstrueeritakse nii uurimus- kui ka ideelooliselt, kuidas Ume saami keelest sai unustatud keel. Oma rolli mängisid selles ka keerulised inimsuhted (Wiklund versus Halász ja Collinder versus Wiklund) ja varasemad keeleteooriad.

Das Umesaami gehört neben dem Pite-, Akkala- und Tersaami zu denjenigen Sprachen, die in der Erforschung der saamischen Sprachen nur eine untergeordnete Rolle gespielt haben. Dies ist teilweise dadurch erklärbar, dass sich die Erforschung der saamischen Sprachen $u$. a. auch aus praktischen Gründen zuerst auf die Sprachen der zahlenmäßig größeren Sprachgemeinschaften konzentrierte und Sprachen mit geringerer Sprecheranzahl überging. Aus der Perspektive des Umesaami ist diese Entwicklung eingermassen überraschend, da das Umesaami relativ zentral in und um Lycksele, dem frühen Zentrum der Konfessionalisierung und Kolonialisierung der nördlichen Gebiete Schwedens gesprochen wurde und das Umesaami in den frühen Verschriftungsversuchen des Saami in Schweden eine zentrale Rolle spielte. Obwohl dadurch eigentlich eine gute Ausgangsstellung für die weitere Erforschung zu erwarten gewesen wäre, nahm die Entwicklung einen anderen Lauf. Aufgrund der territorialen und sprachgeschichtlichen Nähe des Umesaami zum Südsaami und dem dominierenden neogrammatischen Sprachkonzept der frühen Lappologie, wurden bestehende strukturelle Unterschiede übersehen was dazu führte, dass das Umesaami zu einem Dialekt des Südsaami degradiert wurde, in der weiteren Forschung zum Südsaami nur mehr eine untergeordnete Rolle einnahm und dann beinahe vollständig ignoriert wurde. Diese Entwicklung ist verwunderlich, da besonders in der ersten Hälfte des 20. Jahrhunderts umfangreiche Materialien zum Umesaami gesammelt wurden, welche aber aufgrund persönlicher Konflikte innerhalb der Disziplin übergangen oder unveröffentlicht blieben. Dies führte dazu, dass das Umesaami zu der am schlechtesten bekannten saamischen Sprache Skandinaviens wurde. Die Aufgabe dieses Beitrages ist es jene Entwicklung sowohl forschungs- als auch ideengeschichtlich darzustellen und im Hinblick auf die Rolle der persönlichen Konflikte und dem Einfluss neogrammatischer Sprachtheorie genauer zu beleuchten. 
INDEX

Thèmes : linguistique

nomsmotscles Finnois, Hongrois, Norvégiens, Sames, Suédois

Index géographique : Ammarnäs, Araksuolo, Arjeplog, Arvidsjaur, Åsele, Dorotea, Frederika, Hattfjelldal, Luleå, Lycksele, Malå, Norvège, Piteå, Radnejaur, Skellefteå, Sorsele, Stensele, Stockholm, Suède, Tärna, Umeå, Uppsala, Västre Kikkejaur, Vienne, Vilhelmina motscleset ohustatud keeled, saami keeled

disciplines same d'Akkala, same d'Inari, same de Kildin, Same de Lule, Same du Nord, Same de Pite, same sklot, same du Sud, same de Ter, same d'Ume, suédois Languages: Akkala Saami, Inari Saami, Kildin Saami, Lule Saami, North Saami, Pite Saami, Skolt Saami, South Saami, Swedish Ter Saami, Ume Saami

Keywords : endangered languages, Saami languages

Mots-clés : langues en danger, langues sames, historiographie du same, dialectologie same

Index chronologique : XVIIe siècle, XVIIIe siècle, XIXe siècle, XXe siècle

motsclesru ЯЗЫКИ, ПОД УГРОЗОЙ ИСЧЕСНОВЕНИЯ, СААМСКИЕ ЯЗЫКИ 